\title{
SISTEM ISNAD DAN OTENTISITAS HADITS: Kajian Orientalis dan Gugatan Atasnya
}

\author{
Siti Fahimah \\ Sekolah Tinggi Agama Islam Sunan Drajat \\ Email: fahimahsiti@gmail.com
}

\section{Abstract}

In the struggle of contemporary hadith thought, the name of Muhammad Mustafa al Adzami is very well reckoned among scholars of hadith and orientalist. His works made an enormous contribution to the development of the science of hadith, especially in response to criticism of orientalists on the Prophet hadiths. His contribution in the hadith science covers two aspects. First, showing the evidence of hadith writing existed since the early days of Islam. Second, the hadith criticism including sanad or naqd al Kharijites (external criticism), and Matan or naqd al dakhili (internal criticism). He has proved that the criticism principle of sequence and content and the role of logic in the content criticism have a high accuracy to determine the truth of hadith. Besides, Azami is popularly known as defender of the sunnah existence among experts of hadith because of his resistance against the orientalist criticisms on the existence of the Prophet hadith. Among his response against orientalist criticism are on the concept of fitnah, the concept of sunnah, family isnad, the common link theory, the projecting back theory, and the e silentio theory.

Dalam pergulatan pemikiran hadits kontemporer, nama Muhammad Musthafa al Adzami sangat diperhitungkan baik di kalangan para ahli hadits maupun orientalis. Karya-karyanya memberikan sumbangsih besar dalam perkembangan ilmu hadits terutama dalam menanggapi kritik orientalis atas hadits-hadits Nabi. Kontribusi Azami dalam ilmu hadits terbagi menjadi dua. Pertama, pembuktian penulisan hadits yang sudah ada sejak masa awal Islam. Kedua, kritik hadits yang meliputi sanad atau naqd al khariji (kritik ekstern), dan matan atau naqd al dakhili (kritik intern). Azami telah membuktikan bahwa kaidah kritik sanad dan matan serta peran logika dalam kritik matan memiliki akurasi yang cukup tinggi untuk menentukan keshahihan hadits. Selain itu Azami populer dengan sebutan pembela eksistensi sunnah di kalangan ahli hadits karena resistensinya 
atas kritik-kritik yang dilontarkan orientalis terhadap eksistensi hadits Nabi. Diantara tanggapan Azami terhadap orientalis adalah terkait konsep fitnah, konsep sunnah, periwayatan keluarga, teori jalur periwayatan hadits, teori otentisitas hadits, dan teori kebenaran ilmiah.

Keywords: hadith, orientalis, otentisitas hadith

\section{Pendahuluan}

Pergulatan pemikiran kontemporer mengenai hadits, baik yang dilakukan oleh para pemikir muslim (insider) maupun para orientalis (outsider) agaknya juga mengalami dinamika perkembangan yang cukup signifikan. Hal ini tampak dari banyaknya para pengkaji hadits khususnya dari kalangan muslim yang mencoba mengembangkan dan mengkritisi pemikiran tentang hadits, seperti Fazlur Rahman, Muhamad al Ghazali, Yusuf al Qardhawi dan Mushthafa al Azami (Rahman, 1984: 57). Sedangkan dari kalangan non muslim (orientalis), kajian hadits antara lain dilakukan oleh Sprenger, Ignaz Goldjiher, Montgomery Watt, Joseph Schacht dan yang lain (Darmalaksana, 2004: 96). Diakui atau tidak, hadits selalu menjadi kajian yang menarik bagi para pemikir dan cendekia, baik yang mengkajinya sebagai pembela (kalangan muslim) maupun sebagai penentangnya, yang kebanyakan adalah para orientalis (Ensiklopedi Tematis, tt: 81).

Sedangkan dalam pandangan orientalis, berkaitan dengan kajian hadits dapat dibagi kepada tiga kategori yaitu pra Goldjiher, masa Goldjiher dan pasca Goldjiher. Pada masa pra-Goldjiher, kajian hadits lebih dititikberatkan pada sikap skeptisisme atas otentisitas hadits yang menekankan pada valid tidaknya hadits, begitu juga dengan data otentik adanya hadits (Jurnal Kajian Islam, 2005: 10). Pada masa pasca Goldjiher, kajian hadits mengalami perkembangan menjadi lebih berani dengan memberikan tesis bahwa hadits hanyalah kumpulan cerita-cerita belaka, dan semua yang berhubungan dengan hadits adalah palsu termasuk isnad yang ada di dalamnya.

Terlepas dari banyaknya orientalis dalam mengkaji hadits dan juga beragamnya pemikiran mereka, serangan orientalis terhadap hadits dilancarkan secara bertahap, ada yang menyerang matannya (Sprenger, Muir, Goldjiher), ada pula yang menyerang isnadnya (Horovitz, Schacht, Juynboll). Serangan mereka diarahkan ke semua kategori; sebagian menyerang hadits sejarah yang berhubungan dengan sirah (Kister, Scholler, Motzki), sebagian lagi menggugat hadits hukum dan fiqih (Schacht, Powers, Calder), sebagian yang lain menohok hadits tafsir (Wansbrought, Rippin, Gilliot). 
Tertariknya para sarjana Barat terhadap kajian hadits diasumsikan karena hadits adalah istidlal kedua dalam perilaku umat Islam yang tidak mendapatkan legitimasi dari Allah SWT, sehingga yang sering diotak-atik adalah validitas hadits dan juga jalur transmisi yang menjadi bukti otentisitasnya selain adanya realita rentang waktu yang panjang antara Nabi SAW dan masa pembukuan hadits. Tetapi disini yang akan pemakalah soroti adalah seberapa besar pandangan mereka atas pentingnya isnad dan juga penyebarannnya serta teori yang mereka munculkan, khususnya pemikiran Schacht dan juga tanggapan atasnya, baik dari kalangan Muhadditsin sendiri maupun pemakalah yang disatukan dalam satu kerangka dan tidak berdiri sendiri dalam satu poin, karena adanya anggapan bahwa teori Schacht adalah teori yang kemudian menjadi rujukan para orientalis untuk mengkaji hadits selain Goldjiher. Bahkan buku yang dikarangnya menjadi buku 'suci' di kalangan sarjana Barat.

\section{Pembahasan}

Telah dimaklumi bahwa ketika membahas hadits, maka akan dimuat dua bagian; isnad (mata rantai para perawi) dan matan (teks atau lafadz hadits). Kedua bagian ini sama pentingnya bagi para ahli hadits juga para sarjana Barat, karena hal itu dijadikan sebagai legitimasi hukum dalam kehidupan masyarakat muslim. Para sarjana Barat yang notabene skeptis terhadap hadits, mencoba mengkaji, meneliti dan mengkritisinya. Serangan mereka banyak dilancarkan dalam hal isnad dengan tidak menafikan serangan dalam bidang yang lain, karena menurut mereka hal itu adalah sangat problematik (Darmalaksana, 2004: 102). Selain itu hal yang menurut mereka juga problematik adalah keabsahan hadits itu sendiri, umumnya mereka menyatakan bahwa keabsahan hadits diragukan sebagai sabda Nabi Muhammad SAW karena hadits baru ditulis pada masa Umayyah dan Abbasiyah, sehingga isnad atau sanad hadits yang bersambung sampai Nabi SAW meragukan, dan sanad hadits yang dibuat setelah teks hadits itu ada sebagai hasil rekayasa ulama, khususnya ulama hadits ketika melegalisasi pendapatnya untuk menandingi kaum rasionalis. Ulama dianggap belum menggunakan kritik sanad, kritik terhadap produk masa silam dan yang seyogyanya juga menggunakan kritik matan.

\section{Problem Otentisitas Hadits}

Diskursus tentang otentisitas hadits merupakan salah satu hal yang sangat krusial dan kotroversial dalam studi hadits kontemporer. Hal ini boleh jadi disebabkan oleh adanya suatu asumsi bahwa hadits Nabi SAW secara 
normatif-teologis tidak ada garansi dari Allah SWT. Berbeda dengan al Quran yang oleh Allah SWT sendiri diberi 'garansi' akan keterpeliharaanya.

Disamping itu problem otentisitas hadits dipandang sangat signifikan dan sangat penting, karena erat kaitannya dengan pandangan teologis mayoritas umat Islam yang menjadikan hadits Nabi SAW sebagai sumber ajaran pokok kedua setelah al Quran. Bahkan, ia dipandang sebagai Miftah al Quran (kunci untuk memahami al Quran), karena untuk memahami al Quran secara 'syamil' dibutuhkan hadits sebagai bayan, bahkan ada pendapat bahwa hadits dan sunnah Nabi SAW merupakan tafsir dari al Quran itu sendiri dan juga realisasi dari al Quran (Khairuman, 2004: 27). Orang yang meragukan hadits sebagai sumber istidlal, maka pertanyaan yang muncul adalah seberapa besar mereka menerapkan al Quran sebagai ajaran dalam kehidupan sehari-hari? (Langaji, 2006, 67).

Maraknya gugatan atas hadits berawal dari sejarah bahwa hadits tidak terdokumentasi secara resmi sejak awal peradaban muslim, hadits baru dibukukan secara resmi jauh setelah Nabi SAW wafat, yaitu masa khalifah Umar bin Abdul Aziz, sehingga untuk mengatakan hadits sebagai suatu sumber yang otentik sebagaimana al Quran perlu pengkajian yang mendalam. Sebagai konsekwensinya, muncullah para pembela hadits untuk melakukan pembelaan terhadap setiap pendapat yang mencoba meragukan atau bahkan menolak sama sekali terhadap kemungkinan hadits-hadits Nabi SAW yang benar-benar otentik dari Nabi SAW.

Diantara orientalis yang pertama kali mempersoalkan otentisitas hadits adalah Alois Sprenger, dalam tesisnya dia mengatakan bahwa hadits adalah palsu karena merupakan kumpulan anekdot (cerita-cerita bohong tapi menarik). Hal ini didukung oleh teman sejawatnya yaitu William Muir, menurutnya, dalam literatur hadits, nama Nabi Muhammad SAW sengaja dicatat untuk menutupi bermacam-macam kebohongan dan keganjilan. Oleh karenanya, katanya lebih lanjut, dari 4.000 hadits yang dianggap shahih oleh Bukhari paling tidak separuhnya harus ditolak. Sementara itu, Ignaz Goldjiher berpendapat bahwa hadits Nabi SAW sesungguhnya merupakan hasil evolusi social historis Islam abad kedua Hijriyah. Menurutnya, sedikit sekali hadits yang benar-benar asli berasal dari Nabi SAW. Ini artinya Ignaz Goldjiher berusaha memasukkan virus keraguan dalam pikiran umat Islam mengenai otentisitas hadits, kalaupun toh ada itu sangat sedikit sekali.

Asumsi tersebut dilanjutkan Schacht dengan anggapan yang jauh lebih negatif dan juga spekulatif dengan mengatakan bahwa tidak ada satupun 
hadits Nabi SAW yang benar-benar otentik dari beliau, terutama hadits-hadits yang berkaitan dengan fiqih. Lebih lanjut, dia menyatakan bahwa sistem isnad sesungguhnya tidak pernah ada pada zaman Nabi SAW dan hanya ada pada masa belakangan.

Persoalan yang muncul adalah apakah otentisitas hadits secara historis dan ilmiah dapat dibuktikan serta pendekatan apa yang mesti dipakai dan bagaimana caranya. Pertanyaan tersebut memang cukup menggelitik dan membuat para ahli hadits tertantang untuk menciptakan ilmu kritik hadits, baik kritik ekstern (an Naqd al Khariji) yang menyangkut sanad hadits, maupun kritik intern (an Naqd al Dakhili) yang menyangkut matan hadits.

\section{Isnad dan Orientalis}

a. Pandangan Orientalis atas Isnad

Pandangan orientalis atas isnad tidak jauh berbeda dengan apa yang dikenal di kalangan para sarjana muslim yaitu sekumpulan perawi yang mentransmisikan suatu berita, pandangan ini terdapat titik perbedaan dengan pandangan muhadditsin tentang benar tidaknya isnad yang tersebar dalam banyak hadits dan juga kemunculannya.

Dalam pandangan Schacht, isnad merupakan bagian dari tindakan sewenang-wenang dalam hadits Nabi SAW. Hadits-hadits itu sendiri dikembangkan oleh kelompok-kelompok yang berbeda yang ingin mengaitkan teori-teorinya kepada tokoh-tokoh terdahulu (Azami, 1994: 534). Sementara Joseph Horovitz, orientalis Jerman berdarah Yahudi ini mengatakan bahwa besar kemungkinan praktek isnad berasal dari dan dipengaruhi oleh tradisi oral sebagaimana dikenal dalam literatur Yahudi.

Terlepas dari seberapa besar pandangan mereka atas isnad, bagi kelompok lain yang notabene tercatat sebagai orientalis, bahwa pemalsuan isnad sangat kecil kemungkinannya, hal ini diasumsikan oleh H. Motzki, karena bagi dia, baik matan maupun sanad hadits dalam kitab (seperti mushannaf) adalah patut dipercaya, karena tidak mungkin banyaknya periwayat melakukan kebohongan yang terencana, kesimpulannya, ini berbeda dengan Schacht yang menyatakan bahwa hadits adalah seluruhnya palsu, dan hanya sedikit yang tidak dan juga bahwa isnad cenderung membengkak jumlahnya makin ke belakang, juga teorinya bahwa isnad yang paling lengkap adalah yang paling belakangan munculnya.

b. Historisitas Sistem Isnad

Terlepas dari pandangan orientalis atas isnad, ada sebagian mereka yang 
menaruh perhatian cukup besar tentang awal munculnya isnad dalam hadits, diantaranya Josef Horovitz, J.W. Fuck, J. Robson, N.J Coulson dan U. Rubin. kelima orientalis tersebut tampaknya berusaha untuk meneliti kapan sanad itu mulai dipergunakan, tidak lupa juga Caetani dan Sprenger.

Misalnya, menurut Caetani, Urwah adalah orang pertama yang menghimpun hadits Nabi SAW, tetapi ia tidak menggunakan isnad, dan tidak pula menyebutkan sumber-sumbernya selain al Quran. Hal ini sebagaimana terlihat jelas dalam kitab Tarikh al Tabari (Azami, 1994: 535) yang banyak mengambil sumber dari Urwah. Selanjutnya Caetani berpendapat bahwa pada masa Abd al Malik (70-80 H), yakni 60 tahun lebih sesudah Nabi SAW wafat, penggunaan sanad dalam meriwayatkan hadits-hadits Nabi SAW juga belum dikenal, dimulai pada masa antara Urwah dan Ibn Ishaq (w.151 H). Oleh karena itu, sebagian besar dari sanad yang terdapat dalam kitab-kitab hadits adalah bikinan ahli-ahli hadits abad kedua bahkan abad ketiga. Sprenger juga berpendapat yang sama, dimana ia berkata bahwa tulisan-tulisan 'Urwah yang dikirimkan kepada Abd al Malik tidak memakai sanad. Oleh karena itu pendapat yang mengatakan bahwa 'Urwah pernah menggunakan sanad adalah relatif pendapat orang-ulama' mutaakhirin.

Orientalis lain yang meneliti masalah kapan sanad mulai dipergunakan adalah Horovitz, ia membantah keras pendapat Caetani dan Sprenger. Menurut Horovitz, orang-orang yang mengatakan bahwa 'Urwah tidak memakai sanad sebenarnya mereka belum mempelajari kitab-kitab 'Urwah berikut sanadsanadnya secara lengkap. Horovitz menunjuk adanya perbedaan dalam sistem penulisan antara tulisan yang menjadi jawaban suatu pertanyaan, dengan tulisan yang memang sejak semula disuguhkan kepada orang-orang yang terpelajar. Akhirnya Horovitz berkesimpulan bahwa pemakaian sanad dalam meriwayatkan hadits sudah dimulai sejak sepertiga yang ketiga dari abad pertama Hijriyah (Azami, 1994: 532).

Berbeda dengan Horovitz, J.W Fuck mengatakan bahwa isnad adalah sesuatu yang palsu, menurut dia dalam hal isnad, baru disebut oleh para sahabat kecil yang sering disebut seperti Abu Hurairah dan Ibn Abbas dari pada sahabat besar seperti Abu Bakar dan Utsman, fakta ini membuktikan bahwa memang isnad adalah palsu, karena seharusnya yang lebih tahu tentang Muhammad SAW adalah sahabat besar. Tetapi kemudian J.W Fuck melihat kesimpulan dari kebalikannya, menurut dia jika semua isnad adalah palsu kenapa para sahabat masih memakai isnad, dengan tidak memotong sahabat besar, sehingga akan ditemukan keaslian sanad? J.W Fuck tidak selesai berargumen (Berg, 2000: 19). 
Ada juga sarjana Skotlandia, yaitu J. Robson, ia berasumsi bahwa pada pertengahan abad pertama, mungkin sudah ada suatu metode semacam isnad. Sebab pada masa itu sejumlah sahabat sudah wafat. Sedang orang-orang yang tidak bertemu dengan Nabi SAW mulai meriwayatkan hadits-haditsnya. Dengan sendirinya mereka akan ditanya oleh orang-orang, mereka mendengar dari siapa dan darimana mereka mendapatkan hadits-hadits itu. Hanya saja metode sanad secara detail berkembang sedikit demi sedikit setelah itu (Azami, 1994: 533-534).

Kesimpulan pendapat yang dikeluarkan para orientalis di atas yang cenderung negatif (bertentangan dengan data-data yang ada dan ditemukan oleh kebanyakan ahli hadits), ada beberapa yang notabene adalah para orientalis yang mengemukakan secara obyektif pendapat mereka atas teori isnad, diantaranya N. Abbot dan Fuadz Sezqin, keduanya telah berusaha untuk mengemukakan data yang obyektif dengan tidak mereduksi serta menghilangkan data, sehingga tidak parsial. Menurut Abbot bahwa sistem isnad sudah ada sejak masa awal Islam dengan bukti terbentuknya suatu transmisi untuk menyampaikan berita yang saling mereka (sahabat) dapatkan (Berg, 2000: 20). Selain Abbot, ada juga orientalis yang obyektif yaitu Fuadz Sezqin, menurut dia teori isnad sudah ada seiring perkembangan hadits pada seperempat akhir abad pertama dan pertama seperempat abad berikutnya, penyebaran hadits mulai dikumpulkan yang dibarengi dengan jalur transmisinya.

Dalam hal ini Fuadz Sezqin memberikan cara para transmitter menerima hadits, yang oleh para orientalis lain didapatkan kesalahafahaman yaitu ada delapan cara, dan masing-masing mempunyai penekanan tersendiri sama'a, qara'a, ijaza, munawala, kitabah, I'lam al rawi, washiya dan wijadah (Berg, 2000: 21). Metode ini pulalah yang disepakati para ulama ahli hadits, karena dengan cara/metode ini berguna untuk menghindarkan penyelewengan yang dilakukan orang yang tidak bertanggungjawab dan mendekatkan keakuratan setiap hadits yang diperoleh. Apabila metode ini tidak diterapkan, maka tentu akan ada generalisasi setiap hadits yang diperoleh dengan cara apa saja, padahal setiap metode ini mempunyai kekuatan sendiri-sendiri.

\section{Isnad dan Schacht: Sistem Isnad Schacht}

Banyak orientalis mengkaji hadits dari segala segi dan pandangan, tetapi yang mengkaji dan menitikbertakan atas hadits dan mengundang reaksi dari segala kalangan adalah pandangan Schacht, dalam kajiannya, Schacht banyak membicarakan dari segi fiqih (literatur hukum) yang bertitik tolak dari sistem 
isnad. Sanad (sandaran) atau isnad (penyanggah) yang dalam ilmu hadits dimaknai sebagai silsilah (rangkaian), mulai dari sumber pertama sampai yang terakhir, yang atas mereka keaslian sebuah hadits disandarkan, menurut Schacht, otentisitasnya sangat diragukan. Selanjutnya, pandangannya yang nyeleneh adalah dengan mengatakan bahwa adanya isnad adalah hasil buatan ulama mutakhirin dan sangat mengandung kemungkinan salah, karena menurut dia, isnad itu baru muncul pada abad kedua dan ketiga Hijriyah (Rahman dkk., 2002: 65).

Lebih lanjut menurut Schacht, secara keseluruhan, sistem isnad mungkin valid untuk melacak hadits-hadits para ulama abad kedua, tetapi rantai periwayatan yang merentang ke belakang sampai pada Nabi SAW dan para sahabatnya adalah palsu, seperti tesis Schacht "sanad.... "have tendency to grow backward"”, yang artinya bahwa sebenarnya pada mulanya tidak ada sistem isnad, namun kemudian dibuatkan isnad. Jadi ia tidak mempunyai nilai historis sama sekali (Juynboll, 1999: 22). Untuk membuktikan kepalsuan-kepalsuan itu ia lalu menyodorkan teori Projecting Back (Darmalaksana, 2004: 115).

Dalam perkembangan selanjutnya, pendapat-pendapat tersebut tidak hanya dinisbahkan pada tokoh-tokoh terdahulu yang jaraknya masih dekat, melainkan pada tokoh-tokoh terdahulu sekali, bahkan sahabat dan pada akhirnya pada Nabi SAW yang memiliki otoritas paling tinggi. Itulah gambaran atau rekonstruksi terjadinya sanad hadits menurut Schacht, yaitu dengan memproyeksikan pendapat kepada tokoh-tokoh di belakang (Projeting Back). Ia menilai bahwa kebanyakan hadits pada dasarnya merupakan aplikasi yang tidak berada pada teori tersebut. Pada bagian lain ia menilai bahwa sanad hadits hanya merupakan semacam pembenaran terhadap apa yang diyakini sebagai kepercayaan naluriah (Schacht, 1988: 125).

Lebih detailnya, teori Schacht yang dijadikan sebagai argumen adalah sebagai berikut:

1. Sistem isnad dimulai pada awal abad kedua atau paling awal akhir abad pertama (Azami, 2004: 233). Dalam hal ini, Schacht mengabaikan argument Horovitz, dan hanya kembali pada pendapat Caetani:

"bagaimanapun juga, tidak ada alasan untuk beranggapan bahwa praktek penggunaan isnad secara teratur lebih tua daripada awal abad kedua Hijriah"

dan lebih lanjut bahwa pendapat yang mengatakan isnad ada sejak awal. Hal ini sebagaimana dinyatakan Robson dalam rangka mendukung pendapat 


\section{Sistem Isnad dan Otentisitas Hadits}

Schacht dengan mengatakan:

"kritik Schacht yang ditujukan kepada isnad sebenarnya sangat mendasar, ia juga menunjukkan argument kuat yang menyatakan bahwa isnad baru terdapat pada masa belakangan....."

2. Isnad-isnad itu diletakkan secara sembarangan dan sewenang-wenang oleh mereka yang ingin mencari legitimasi atas sanad-sanad awal dan juga doktrin klasik.

Dari pengakuannya mengenai isnad, Schacht berkomentar bahwa ketika dia mempelajari hadits-hadits yang berkaitan dengan masalah fiqih serta perkembangannya, ia berkesimpulan bahwa isnad adalah bagian dari 'tindakan sewenang-wenang' dalam hadits. Hadits-hadits itu sendiri dikembangkan oleh kelompok-kelompok yang berbeda yang ingin mengaitkan teori-teorinya kepada tokoh-tokoh terdahulu.

Isnad dalam pandangan Schacht juga sering diletakkan bersama-sama secara sembarangan. Representasi kelompok yang doktrinnya diproyeksikan ke belakang sampai pada sumber klasik dapat dipilih secara acak dan diletakkan dalam isnad, karenanya didapatkan sejumlah alternatif nama dalam isnad-isnad lain yang identik, dimana pertimbangan-pertimbangan lain akan meniadakan kemungkinan periwayatan doktrin lama yang asli yang dilakukan beberapa orang. Untuk mendukung teorinya, Schacht mengajukan beberapa contoh yang diambil dari generasi sebelum Malik, tetapi menurut pandangan Azami bahwa contoh yang dikemukakan Schacht perlu diteliti dan dikaji ulang.

Lebih lanjut, menurut Azami Schacht tidak memberikan indikasi atau bukti terhadap hakikat 'pertimbangan-pertimbangan lain' yang akan meniadakan kemungkinan periwayatan doktrin lama yang asli yang dilakukan oleh beberapa orang, karenanya harus diasumsikan beberapa kemungkinan mengenai hal ini: Apakah orang-orang itu sendiri yang tidak ada? Apakah mereka tidak memiliki kesempatan untuk mempelajari doktrin itu dari ulama-ulama yang sama atau berbeda? Apakah kandungan hadits itu tidak mungkin terjadi dalam konteks masa itu? Sebenarnya mereka semua adalah orang-orang yang asli ada secara historis, semuanya berada pada generasi yang sama atau hidup di kota yang sama atau hidup di kota yang sama selama periode 30 sampai 40 tahun dan tidak ada kemustahilan dalam hal itu (Azami, 2004: 237).

1. Perbaikan isnad secara bertahap

Salah satu pendirian Schacht yang sentral adalah bahwa isnad-isnad 
itu "meningkat" secara bertahap oleh pemalsunya, isnad yang tidak lengkap sebelumnya dilengkapi pada waktu koleksi-koleksi klasik. Sumber-sumber tambahan diciptakan pada masa Syafi'i untuk menjawab penolakan-penolakan yang dibuat untuk hadits-hadits yang dilacak ke belakang sampai pada satu sumber (Azami, 2004: 258).

Teori utama Schacht lainnya bahwa isnad-isnad baru dan sumber-sumber tambahan dibuat dengan tujuan mempertegas suatu doktrin dengan bukti yang benar-benar independen. Schacht berkesimpulan bahwa dalam teori ini adanya rawi-rawi tambahan itu dengan adanya perbaikan dan pertumbuhan ke belakang, isnad-isnad itu terus menyebar, maka pembuatan sumber-sumber atau periwayat-periwayat tambahan untuk doktrin atau hadits yang sama adalah untuk menjawab keberatan yang biasa digunakan terhadap hadits yang terisolasi.

Sementara dalam pandangan Azami, bahwa argumen-argumen yang dikeluarkan Schacht hanya disandarkan pada teori e silentio dan kekurangpahamannya terhadap metode penggunaan isnad yang digunakan para ulama masa awal. Pandangan Schacht hanya sekedar pengandaian dan bukti-bukti yang dihadirkan meragukan (Azami, 2004: 267).

2. Isnad keluarga

Isnad keluarga adalah salah satu dari teori-teori Schacht yang lemah, tapi bagaimanapun juga mengarahkan Schacht untuk menolak banyak hadits dan isnad yang benar-benar otentik, dan dia berkeyakinan bahwa semua isnad keluarga adalah palsu, karena dimungkinkan disana adanya perencanaan atau kongkalikong antar keluarga untuk menciptakan suatu hadits (Azami, 2004: 279).

Dalam ulum al hadits, hal ini dikatakan riwayat yang disebut 'Alaqat Ruwat' yang didalamnya ada riwayat dari keluarga, seperti periwayat dari saudara, anak dari bapak atau sebaliknya ('Itr, 1972: 23). Semua itu diteliti dengan sedemikian rupa oleh para muhadditsin dengan melewati jarh wa ta'dil. Diantara yang telah membahas seberapa pentingnya riwayat 'keluarga' adalah Ibnu Shalah peletak batu pertama teori dan macam-macam hadits dalam karangannya "Muqaddimah Ibnu Shalah". Dengan demikian maka tidak bisa dikatakan dengan mudah bahwa sanad atau riwayat keluarga adalah palsu. Demikian juga dalam masalah periwayatan hadits, walaupun hadits diriwayatkan dari keluarga, hal itu tidak mengurangi ketelitian para periwayat untuk menilainya dengan adil, sehingga tidak relevan lagi kalau Schacht mengatakan bahwa semua sanad keluarga adalah palsu dan tidak terbukti. 
3. Keberadaan common narrator (perawi) dalam rantai periwayatan itu merupakan indikasi bahwa hadits itu berasal dari masa periwayat itu

Teori Schacht lainnya adalah bahwa keberadaan common link (tokoh penghubung) dalam rantai periwayatan mengindikasikan bahwa hadits itu berasal dari masa tokoh tersebut, dan hal ini adalah petunjuk untuk menentukan waktu terjadinya pemalsuan (Azami, 2004: 281).

Sementara dalam pandangan ulama klasik, misalnya oleh Tirmidzi pada bab kesimpulan dalam koleksi hadits miliknya, dia menyebut hadits-hadits dengan common link N.N. sebagai common link dalam isnad mereka. Haditshadits dengan common link N.N. dan isnad-isnad itu membentuk sebagian besar hadits yang disebutnya gharib, yakni diriwayatkan oleh seorang periwayat pada satu tingkatan. Pendekatan Schacht ini jika diteliti dapat dijelaskan melalui contoh modern; seorang reporter surat kabar yang mengumpulkan informasi dari berbagai sumber dan kemudian mempublikasikan temuan-temuanya dalam surat kabar akan dianggap memalsukan berita karena ribuan pembaca hanya dapat merujuk padanya sebagai sumber mereka.

Kemudian di sisi lain, penolakan Schacht terhadap teori sistem isnad sebenarnya dimaksudkan untuk 'mendongkel' otoritas sunnah yang oleh kaum muslim dijadikan salah satu sumber ajaran. Jika dia gagal menyerang dan meragukan al Quran, maka sasaran empuknya adalah sunnah Nabi SAW. Untuk menyerang sunnah Nabi SAW, maka sistem isnad yang menjadi jalan sampainya sunnah ke kita, dia ragukan bahkan ditolaknya sama sekali. Tampaknya dalam hal ini, Schacht sengaja mengabaikan kesaksian dan pernyataan al Quran yang memerintahkan umat Islam untuk mengikuti sunnah Nabi SAW. Disinilah mungkin salah satu ketidakjujuran Schacht.

Pentingnya sanad dalam ranah hadits tidak diabaikan begitu saja karena sanad adalah ajaran Agama, seperti hadits Nabi SAW yang dinyatakan Ibnu Mubarak:

\section{الإسـناد من الدين ولولا الإسـناد لقال من شـاء ماشاء}

Dari sini penelitian sanad sangat ditekankan. Selain itu, sanad adalah perantara, sehingga tidak ada hadits kalau tidak ada sanad. Sanad juga menjadi pangkal kebenaran atau sebagai bukti bahwa sang penerima berita tidak mengada-ada, sanad juga merupakan standar ilmiah, seperti yang dikatakan Qarad Abu Nuh (Abdurrahaman, 1999: 106):

\section{كل علم ليس فيه حدثنا أو اخبرنا فهو خل وبقل}

"Setiap ilmu yang tidak ada perkataan haddatsana (telah menyampaikan hadits kepada kami) atau akhbarana (telah memberitakan kepada kami) maka lemah dan tidak kuat". 
Pernyataan diatas dilandasi kekhawatiran ulama terhadap orang yang rajin mengumpulkan segala yang dinisbahkan kepada Nabi SAW, meskipun tidak mempunyai dasar ilmiah, sehingga diragukan keabsahannya. Bahkan kalau dilihat dalam khazanah Islam, untuk melihat bagaimana pentingnya suatu sanad dalam penelitian para muhadditsin ada beberapa bidang kajian yang dihasilkan, bisa dilihat misal dengan adanya tradisi 'Naqd'. Secara eksplisit, aktivitas naqd al hadits senantiasa diarahkan pada kritik sanad dan matan, dan dalam kritik sanad senantiasa diarahkan pada penilaian para rawi dan metode periwayan yang digunakan (Azami, 1976: 391). Kritik sanad ini ditujukan untuk melihat kredibilitas para rawi diakui dan apakah tahammul ada'nya menunjukkan otentisitas hadits Nabi SAW.

Karena fokus kajian kritik sanad adalah kualitas para rawi, maka diperlukan juga 'ilmu jarh wa ta'dil' dalam hal hadits (Al Khatib, 1996: 227). Melalui ilmu ini akan tersingkap berbagai informasi yang terkait dengan keadaan para rawi hadits yang terlibat dalam periwayatan hadits, dan hal ini juga adalah untuk menghindari adanya suatu pemalsuan bahkan kekurangkredibelan orang untuk menyampaikan berita, dan diantara yang menjadi titik sentral adalah kejujuran, perilaku sosial, serta kekuatan hafalan seorang penyampai berita (perawi) dan hal ini (jarh wa ta'dil) telah berlaku lama, jauh sebelum para orientalis berusaha mencari kekeliruan dalam hadits yaitu pada masa sahabat, antara lain Ibnu Abbas dan Anas bin Malik. Adapun dari kalangan tabi'in antara lain al Sya'bi (w.104 H) dan Ibnu Sirin (w.110 H), sementara itu ulama lain tercatat Ibnu Mubarak (w.181 H), Ibn Uyainah (w.197 H), Abdur Rahman bin Mahdi (w.198 H), Yahya bin Ma'in (w. 233 H), Ahmad bin Hanbal dan lain-lain.

Selain para tokoh ini dalam pembahasan tentang rijal (kritik sanad) akan banyak dijumpai karangan yang dihasilkan serta pentingnya para muhadditsin menaruh perhatian atas kredibilitas seorang perawi, bahkan mereka tidak segan untuk mengoreksi (mencacatkan bahkan menghujat) walaupun itu gurunya sendiri, yang kemudian dijumpai ulama yang mutasyadidin, mutawasithin, dan juga mutasahilin dalam menilai seorang perawi.

Dalam teori-teori ahli hadits, keabsahan dan otentisitas sanad hadits merupakan unsur yang terlibat dalam menentukan keabsahan dan otentisitas hadits itu sendiri. Tidak ada ahli hadits yang taqwa yang menganggap bahwa hadits mauquf adalah hadits marfu' atau sebaliknya. Begitu pula, tidak ada orang yang menganggap hadits yang putus sanadnya sebagai hadits yang 
bersambung sanadnya. Hal ini tidak perlu dikhawatirkan terjadi di kalangan ahli-ahli hadits.

Dalam tradisi hadits banyak dijumpai baik naqd al khariji yaitu kritik yang mempunyai sasaran dengan masalah-masalah di luar materi hadits tetapi juga naqd dakhili adalah kritik terhadap matan. Berakar dan berawal dari usaha pencarian kebenaran dalam ranah kajian matan tersebut, ilmu hadits berkembang mekar menjadi beragam, bisa dilihat dengan munculnya beberapa istilah seperti 'ilmu mukhtalif al hadits, 'ilmu 'ilal al hadits, 'ilmu gharib al hadits, 'ilmu nasikh wa al mansukh, ilmu Tashif wa Tahrif, ilmu Talfiq al Hadits dan lain-lain. Dengan demikian kajian orientalis tidak lagi relevan dan hanya bersifat menggugat atau bahkan hanya sebuah wacana.

Sementara secara khusus ulama yang 'gerah' dengan tesis yang dikeluarkan para orientalis terutama untuk menyikapi teori yang dimunculkan Schacht dan menyanggahnya secara langsung dan ilmiah adalah Azami, beliau sebagai pakar hadits memberikan tanggapan, sanggahan, dan pembatalan atas teori Schacht dengan kajian dan data yang lebih sesuai. Pertama, kekeliruan orang-orang orientalis secara umum (juga Schacht) dalam memilih materi studi sanad sebagai kajian, seperti mereka umumnya dalam meneliti sanad selalu menggunakan kitab-kitab sirah, padahal ada perbedaan yang signifikan antara kitab hadits dan sirah. Kedua, parahnya lagi, Schacht selalu melakukan generalisasi terhadap hasil kajiannya terhadap kitab-kitab fiqih, seakan-akan tidak ada kitab khusus mengenai hadits. Padahal ada perbedaan yang mendasar antara kitab-kitab hadits dengan kitab-kitab fiqih, hasilnya mereka berkesimpulan bahwa teori sistem isnad adalah ahistoris (Azami, 2004: 233).

Adapun perbedaan yang cukup mendasar dari kajian fiqih dan hadits adalah dalam kitab-kitab fiqih biasanya: 1) terjadi pembuangan sebagian sanad untuk mempersingkat pembahasan, oleh karenanya cukup disebutkan bagian dari matan yang berkaitan dengan pembahasan; 2) membuang sanad seluruhnya, dan langsung menyebutkan hadits dari sumber pertama (Rasululullah SAW); 3) penggunaan kata "sunnah" untuk menunjuk kepada perbuatan Nabi SAW tanpa menyebut hadits dan sanadnya (Abdurrahman, 1999: 101-102).

Lebih lanjut Azami berkesimpulan bahwa dalam penelitiannya, Schacht tidak memperhatikan poin-poin diatas, sehingga dia berkesimpulan bahwa sanad itu bikinan para ulama belakangan, padahal dalam kenyataannya, kitab-kitab fiqih dan kitab-kitab biografi tidak dapat dijadikan sebagai obyek penelitian sanad hadits, baik ditinjau dari gejala adanya sanad itu sendiri, pertumbuhannya, maupun perkembangannya (Azami, 2004: 246). 
Bagi Azami, otentisitas hadits itu tetap dapat dibuktikan secara ilmiah dan historis. Beliau menunjukkan fakta bahwa semua masalah mengenai hadits Nabi SAW bertumpu pada masalah sentral tentang status sunnah yang merupakan sumber ajaran Islam kedua. Lebih lanjut beliau berargumen bahwa untuk memperoleh otentisitas hadits, maka seseorang harus melakukan kritik hadits menyangkut nash atau dokumen dengan memakai beberapa metode, dan salah satunya adalah dengan metode perbandingan. Hal ini seperti yang dikatakan oleh Ibnu Mubarak: "untuk mencapai pernyataan yang otentik, orang perlu membandingkan kata-kata para ulama satu dengan yang lain” (Azami, 2004: 87).

Adapun secara umum, rumusan metodologi yang ditawarkan Azami untuk membuktikan otentisitas hadits adalah sebagai berikut (Rahman dkk., 2002: 72):

1. Membandingkan hadits-hadits dari berbagai murid seorang syaikh.

2. Membandingkan pernyataan-pernyataan dari seorang ulama yang dikeluarkan pada waktu yang berlainan.

3. Membandingkan pembacaan lisan dengan dokumen tertulis.

4. Memperbandingkan hadits-hadits dengan ayat al Quran yang berkaitan.

Walaupun terlihat, agaknya Azami hanya memperhatikan kritik khariji yaitu dalam masalah sanad saja, tetapi tidak dipungkiri bahwa beliau juga merambah dalam hal matan dengan bukti yang menurutnya bahwa pendekatan rasional tidak selamanya dapat diterapkan dalam metode kritik hadits, seperti hadits yang Azami coba lihat dan kritik adalah tentang Nabi SAW yang tidur dengan berbaring pada lambung kanan, dan sebelum pergi tidur beliau biasa membaca doa-doa tertentu.

Secara kritis, dalam menguji keotentikan hadits tidak hanya dilakukan Azami, tetapi juga oleh para orientalis yang bersikap 'objektif dalam mengkaji hadits seperti N. Abbot, Fuadz Sezqin dan lain-lain.

\section{Simpulan}

Sikap dan pandangan orientalis terhadap hadits Nabi SAW, tidak jauh berbeda dengan apa yang mereka tuduhkan kepada Nabi Muhammad SAW dan Kitab suci al Quran. Mereka mempunyai anggapan bahwa hadits Nabi SAW itu adalah buatan para sahabat, bukan dari perkataan Nabi SAW. Hadits 


\section{Sistem Isnad dan Otentisitas Hadits}

sebagai dalil serta istinbat kaum Muslim dicoba untuk dibongkar ulang oleh para kaum orientalis dengan sasaran sanad dan juga isinya (matan). Schacht misalnya, yang begitu berani dengan kesimpulannya yang mengatakan bahwa semua hadits Nabi SAW adalah palsu dan hanya hasil proyeksi orang-orang setelahnya, baik itu kelompok aliran fiqih maupun ahli-ahli hadits, sama-sama meriwayatkan hadits, oleh karena itu maka keabsahan dan otentisitas hadits Nabi SAW tetap saja harus diragukan, walaupun hadits tersebut misalnya dilengkapi dengan sanad. Kalau diteliti kembali adanya tradisi kritik hadits, baik dalam hal matan maupun sanad, adalah untuk membuktikan kehati-hatian kaum muslim dan tidak ceroboh dalam mengambil hadits sebagai sumber.

Terlepas dari tradisi itu, tesis yang dikeluarkan oleh para kaum orientalis kebanyakan bahkan mayoritas adalah menggugat keotentikan hadits, bahkan menurut Herbert Berg kajian para orientalis itu hanyalah sebuah kajian yang tak berujung bagaikan lingkaran setan, menggugat, meragukan dan tidak memberikan solusi.

Oleh karena itu, tulisan-tulisan orientalis mengenai Islam dan segala sumber serta aspek-aspeknya harus diwaspadai dan dibaca secara kritis, tidak boleh diterima apa adanya dan ditelan begitu saja, sebab yang mereka kemukakan menyerupai virus penyakit pemikiran.

\section{Daftar Pustaka}

Abdurrahman, M. 1999. Pergeseran Pemikiran Hadits; Ijtihad al Hakim dalam Menentukan Status Hadits. Jakarta: Paramadina.

Azami, M.M. 1994. Hadits Nabi dan Sejarah Kodifikasinya. Diterjemahkan oleh Ali Musthafa Yakub. Jakarta: Pustaka Firdaus.

Azami, M.M. 2004. Menguji Keaslian Hadits-Hadits Hukum; Sanggahan atas The Origins of Muhammadan Jurisprudence Joseph Schacht. Jakarta: Pustaka Firdaus.

Azami, M.M. 976. Dirasat fi al Hadits an Nabawi. Jami'ah Riyadh: Tanpa Penerbit.

Al Khatib, Ajjaj. 1996. Ushul al Hadis. Diterjemahkan oleh Qadirun. Jakarta: Gaya Media Paratama.

Berg, Herbert. 2000. The Development of Exegesis in Early Islam; The Authencity of Muslim Literature from The Formative Period. Surrey: Curzon Press Richmond. 
Darmalaksana, Wahyudin. 2004. Hadits di Mata Orientalis; Telaah atas Pandangan Ignaz Goldjiher dan Joseph Schacht. Bandung: Benang Merah Press.

Ensiklopde Tematis. Tt. Ilmu Hadis Sebagai Sumber Pemikiran. Jakarta: PT Ichtiar Baru Van Hove.

Itr, Nuruddin. 1972. Al Madkhal ila Ulum al Hadits. Madinah: al Maktabah al 'Ilmiyah.

Juynboll, G.H.A. 1999. Kotroversi Hadis di Mesir (1890-1960). Diterjemahkan oleh Ilyas Hasan. Jakarta: Mizan.

Jurnal Kajian Islam. 2005. Al Insan. Volume 1, Nomor 2.

Khairuman, Badri. 2004. Otentisitas Hadits; Studi Kritis atas Kajian Hadits Kontemporer. Bandung: PT. Remaja Rosdakarya.

Langaji, Abbas. 2006. Inkar al Hadits dan Pengaruhnya Terhadap Masyarakat Muslim di Kota Palopp (disertasi). Jakarta.

Rahman, Fazlur. 1984. Islam. Bandung: Pustaka Salman.

Rahman, Fazlur dkk. 2002. Wacana Studi Hadits Kontemporer. Yogyakarta: Tiara Wacana.

Schacht, Josep. 1988. "Law and Justic" dalam The Cambridge History of Islam. Jakarta: INIS. 